\title{
O FUTURO DA ESCOLA: UMA ETNOGRAFIA SOBRE A RELAÇÃO DOS JOVENS COM O CONHECIMENTO
}

\section{THE FUTURE OF SCHOOL: AN ETHNOGRAPHY ON THE RELATIONSHIP OF YOUNG PEOPLE WITH KNOWLEDGE}

\section{EL FUTURO DE LA ESCUELA: UNA ETNOGRAFÍA SOBRE LA RELACIÓN DE LOS JÓVENES CON EL CONOCIMIENTO}

Luis Paulo Borges ${ }^{1}$

Resumo: A presente tese tem como objeto de estudo a relação dos jovens estudantes do Ensino Médio com o conhecimento escolar. Pauta-se na abordagem teórico-metodológica etnográfica, situada na fronteira entre a antropologia e a educação. Assim, foram utilizados o caderno de campo, notas etnográficas, descrição densa, entrevistas, fotografias, observação participante e produções textuais como formas de apreender um recorte da realidade social. Articulam-se as categorias conhecimento escolar, juventudes e futuro, privilegiando os teóricos Bernard Charlot, Carmen Gabriel, Alice Lopes e Elizabeth Macedo, Juarez Dayrell, José Pais, Gilberto Velho, Clifford Geertz, Carmen de Mattos, Homi Bhabha, W. Pinar e Arjun Appadurai. A tese questionou: como jovens estudantes do Ensino Médio de uma escola pública da rede estadual do Rio de Janeiro se relacionam com o conhecimento socializado pela escola? Como objetivo geral, estudou e investigou, através da ótica dos próprios participantes da pesquisa, qual é o papel da escola diante do conhecimento escolar. Dessa forma, emergiram três categorias analíticas: i) o conhecimento escolar, partindo da relação entre as instâncias críticas e pós-críticas, colocando em xeque as concepções de escola e suas contradições presentes na modernidade, além de um confronto entre o texto curricular proposto na Base Nacional Curricular Comum (BNCC) com as vozes discentes encontradas na pesquisa; ii) a ideia de juventudes em trânsito abordando a relação dos jovens com o conhecimento escolar, compreendendo os processos educacionais e a própria imagem e concepção de juventude em sua relação com a escola. Opera-se numa lógica de que há uma polifonia nas vozes discentes que podem ser escutadas como forma de uma produção curricular pensando os dissensos como caminhos possíveis. iii) por fỉm, articula-se a categoria futuro da escola, e dos seus sujeitos, em um processo de dupla transitividade: o futuro como temporalidade e o futuro como emergência e (re)imaginação das relações sociais dos jovens com o

Submetido em: 14/06/2018 - Aceito em: 09/09/2018 - Publicado em: 26/01/2019

${ }^{1}$ Professor do Instituto de Aplicação Fernandes Rodrigues da Silveira da Universidade do Estado do Rio de Janeiro/ CApUERJ. 


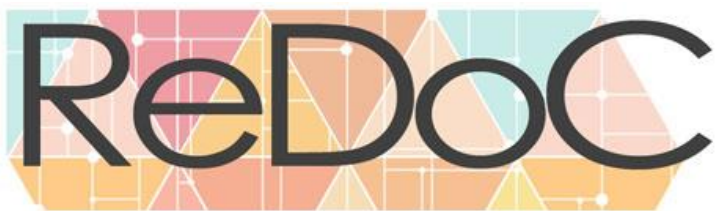

\section{Revista Docência e Cibercultura}

conhecimento e a escola. Deste modo, trabalha-se o futuro como uma categoria etnográfica sob rasura, em que as vozes discentes indicam que escola e que conhecimento hão de existir. À guisa de conclusão, defende-se a tese de que o conhecimento escolar, entendido como atos de significação, é uma dimensão criadora dos modos de subjetivação e diferença, capaz de permitir a emergência de transformações sociais no contexto escolar que ocorrem a partir das vozes dos seus sujeitos pautando-se na enunciação cultural. Descrevem-se as vozes de alunos e alunas que se misturam à interpretação do pesquisador (re)imaginando a escola do futuro, que só se faz existente a partir de mudanças profundas em sua arquitetura moderna, a partir da sua reconstrução, sob rasura, e inserção na pós-modernidade.

Palavras-chave: Conhecimento escolar. Cultura escolar. Escola contemporânea. Etnografia. Futuro. Juventude.

Disponível em: 〈http://proped.pro.br/teses/teses_pdf/1708182009_1-541-DO.pdf> 